Poffenberger, Mark

1980 Patterns of Change in Nepal Himalaya. Delhi: Macmillan.

Regmi, Mahesh Chandra

$1971 \quad$ Study of Nepalese Economic History. New Delhi: Manjusri Publishing House.

Regmi, Mahesh Chandra

1976 Land Ownership in Nepal. Berkeley: University of California Press.

Regmi, R. R.

1992

State of Anthropology in Nepal. Paper Presented at the National Congress of Sociology/Anthropology in Nepal. Kathmandu: Anthropological/Sociological Society of Nepal.

Schumacker

1975

Small is Beautiful: A Study of Economics as if People Mattered. London: Sphere Books.

Schumacker

1979

Goodwork. London: Janathan Cape.

Sharma, Prayag Raj

1089

"Nepali Culture and Society: Reflections on Some Historical Currents" In Kamal P. Malla (ed.) Nepal: Perspective on Continuity and Change. Kathmandu: Research Centre for Nepal and Asian Studies, Tribhuvan University.

Spicer, Edward H

1952

Human Problems in Technological Change: A Case Book. New York: Russel Sage Foundation.

Wake, C. J.

1980
Vikas: Evolution in Nepal. Kathmandu: Centre for Nepal and Asian Studies, Tribhuvan University.

\section{POPULATION DYNAMICS AND ENVIRONMENTAL DEGRADATION IN NEPAL: AN OVERVIEW}

\section{Prelude}

By Laya Prasad Uprety*

This paper, in general, makes an endeavour to demonstrate how the population growth in Nepal has been conducive to the environmental degradation. More specifically, this paper is intent on dealing with four objectives, viz., (i) to assess the trends and causes of the population growth; (ii) to assess the increasing demands of growing population on the environment; (iii) to assess the environmental degradation resultant from the population pressure, and (iv) to assess the impact of environmental degradation on the agrarian economy of Nepal.

\section{Trends and Causes of Population Growth: A Glimpse of Population Dynamics}

In Nepal, population has been unprecedentedly growing. Nepal's population which was only 5.6 million in 1911 increased to 18.4 million in 1991. According to the national census of 1991, the population has now been increasing at 2.1 percent per year. Presumably, this rate of growth continues to rise even in the future if the government does not formulate and implement effectively some practical population policies and programmes to curb the population growth. Many independent variables such as economic value of children in Nepalese agrarian economy, reduction of infant mortality and morbidity owing to the medical treatment facilities (though in limited extent), malaria eradication in the Tarai (shifting of the destination of hill

Mr. Laya Prasad Uprety is the Lecturer in Anthropology at the Central Department of Sociology/Anthropology, Tribhuvan University, Kirtipur, Kathmandu. 
migrants from India to the Tarai), rurality of population in composition, immigration from India, early nuptiality, unavailability of birth control advice and contraceptive devices in the outlying parts, illiteracy/lack of education, fatalistic attitude, etc; have been contributing to this rapid growth of population. Never in the history of mankind have as many people populated the Himalayas as today and there will be more tomorrow (Rieger, et al. 1976). In order to have a clear understanding of the trends of population growth in Nepal, we have to look at the longitudinal demographic data as presented in the following Table 1 .

Table 1: Population Size and Growth, Nepal, Census Years 1911-1991

\begin{tabular}{lcc}
\hline \multicolumn{1}{c}{ Census Years } & Population Size & Geometric Growth Rate \\
\hline 1911 & $5,638,749$ & - \\
1920 & $5,573,788$ & -0.13 \\
1930 & $5,532,574$ & -0.07 \\
1941 & $6,283,649$ & +1.16 \\
$1952 / 54$ & $8,256,625$ & +2.30 \\
1961 & $9,412,996$ & +1.65 \\
1971 & $11,555,983$ & +2.07 \\
1981 & $15,022,839$ & +2.66 \\
\hline 1991 & $18,491,097$ & +2.08 \\
\hline
\end{tabular}

Sources : CBS 1985 - Intercensal Changes of Some Key Census Variables, Nepal 1952/54 - 81. p.13 and Population Monograph of Nepal (1995) and Statistical Pocket Book, Nepal (1998).

The above table provides the population data from 1911 onwards. However, quoting several foreign authors, V.B.S. Kansakar (1989) notes that before the 1911 census, the population was estimated at $3,661,200$ persons (Fraser, 1920), 4 million in 1850s (Oldfield, 1880), 5 million in 1879 (Husain, 1970 ) and 5.2 million to 5.6 million at the beginning of the $20^{\text {th }}$ century (Vansittart, 1906).

Though Nepal has a long history of census enumeration, the scientific census enumeration started only in 1952/54 with the establishment of separate organization. The censuses before $1952 / 54$ were taken by local revenue agents for various administrative purposes. The population of Nepal decreased by one percent between 1911 and 1920 and similar trends can be clearly observed between 1920 and 1930. The absolute decline in population size between 1911 and 1920 may be attributed, among others, to : (a) the effect of world wide influenza epidemic in 1918 which had also passed through Nepal and took the lives of a large number of population, and (b) the heavy loss suffered by the Nepalese men serving with the allied forces during the First World War (CBS, 1985. 7-8).

In the 1930 census, the population decline can also be attributed to the under-enumeration due to the lack of separate organization and the apprehension of being conscripted into the army for possible war against Tibet in 1929. There was 1 percent per annum population growth rate during the intercensal period 1930-1941. This modest growth was followed by high rate of 2.3 percent growth rate during the intercensal period 1941-1952/54. Improvement in the management of census taking, return of men serving with foreign armies after the second world war and better coverage were some of the contributing factors to this rapid increase of population (CBS, 1985).

Between 1952/54 and 1961, the population growth rate was 1.6 percent per annum. Though not plausible, Nepalese experts on population studies have argued that this decline might be due to the over-enumeration in 1952/54. After 1961, the Nepalese population has been rapidly increasing. During the intercensal period of 1961 and 1971, the population growth rate was 2.07 percent per annum. The unprecedented population growth rate, that is 2.6 per annum, can be observed between the intercensal period of 1971 and 1981. But the annual growth rate between 1981 and 1991 is a little lower, that is, 2.1 percent.

Historically, Nepal's Tarai region was densely forested and was highly infested with malarial diseases. But the soil is highly productive and whoever went there in search of cultivable land was fallen into the prey of formidable malarial disease. Hence, this Tarai region was known by the name of "black waters". Very few of autochthonous tribes who had genetically developed resistance against malaria were found in scattered 
settlements. But in the 1950 s, a USAID - sponsored malaria control program started the spraying of DDT (Dichlorodiphenyl-trichloroethane insecticide) in malarial areas and the fatal malarial disease was almost controlled. Then, this Tarai region, being the most fertile, began attracting a large number of migrants from the hill and mountain regions.

Since 1970's, BCG (Bacillus Calmette-Guerin) immunization began to be provided to all the children under 15 years of age which substantially reduced the tuberculosis incidence. Diarrhoea has been drastically reduced due to the availability of Jivan Jal (oral rehydration powder) even in the outlying parts of the country. Smallpox is almost eradicated through vaccination. Cholera is also being controlled. Leprosy, gastrointestinal disorders, etc. have also been reduced due to the medical facilities to some extent. Although Nepal is still poor in medical field compared with many other Asian countries, modern medical facilities have been working for lowering the infant and adult mortality, increasing the life expectancy and thereby contributing to the population growth.

Besides the gradual development of hospital-based medical care, the government is also setting up Ayurvedic clinic and small health centers to serve the needs of Nepal's dispersed populations. These small health centers have been staffed by health auxiliaries and paramedical personnel. According to the national census of 1991, the life expectancy of males and females has risen to 55.0 and 53.5 years, respectively (CBS, 1995). Thus, substantial achievements have been made in reducing the morbidity and mortality.

Before malaria was eradicated in the Tarai of Nepal, both mountain and Tarai regions had low density of population. People of the hill did not like to risk their lives in the hot and malarial Tarai although natural increase of population in the hill areas was placing tremendous pressure on the arable land whereas ample land was unused in the Tarai. Earlier government of Nepal tried to attract the immigrants from India to settle in the Tarai and achieved modest success. But the people of the hill, due to the population pressures, started used to emigrate to Assam, Darjeeling, (both being parts of India),
Sikkim (before a semi-protectorate of India but now annexed to it), Burma, and Bhutan. The coal and tea industries developed in many Indian provinces offered the job opportunities to Nepalese unskilled labour forces (Regmi, 1978). Besides these, many adult males of the hill region of Nepal were employed as mercenary soldiers in British East India company.

Prior to the 1961 census of Nepal, many hill Nepalese used to emigrate to India but after that there has been a considerable decline in the net emigration. Banister and Thapa argue that the main reason why the long-term migration of Nepal-bom persons became less pronounced in the 1960's is that the destination of many migrants leaving the hills of Nepal shifted from India to the Tarai. This change was due primarily to malaria control and sudden availability of good agricultural land in the Tarai (Banister and Thapa, 1981: 78). All this contributed to the rise of Nepalese population after 1961.

Children in Nepalese agrarian economy have very high economic value. Older children take care of younger siblings and thereby help free their parents to be involved in various productive activities. Analogously, they also look after their livestock and fetch water and firewood. Besides these, older children also help their parents in various agricultural activities. Children in Nepalese society are considered as the main economic security during the old age. In discussing the fertilityrelated attitude, Poffenberger demonstrates the economic value of the children in the following way:

\begin{abstract}
In a country where until recently labor was a scarce commodity, the economic value of the children was great. Traditionally, one of the clearest determinants of how much land a family controlled and how wealthy it was, was the number of family members available to bring land under cultivation and work it ... Certainly, the association between many children and wealth of security is a strong one among virtually all the hill cultures of Nepal ... (Poffenberger, 1980 : 84).
\end{abstract}

Desperately poor people still think that more the working children a household has, the more economically viable it gets. Birth of a child is considered to be a blessing but not a curse. 
In the patrilineal Nepalese society, there has been a culture of giving preference to sons. In the orthodox Hindu culture, sons are needed to conduct various ritual activities after the death of parents. Traditionally, it is the duty of a man to get married and produce at least one son before he dies which helps him in paving the path to reach "Swargd' meaning 'heaven'. Because of this 'son preference culture', people still hope to produce a son even after the birth of half a dozen daughters. Another reason of giving 'preference to son' is that girls leave their parental home after they get married and it is only sons who live with the parents and work as economic security during the old age. Sons also keep the 'name' of the family and inherit the parental property. All these traditionally-embedded notions also contribute to the rapid growth of population.

Early nuptiality, being universal in the Nepalese sociocultural tradition, also contributes to the rise of population. The legal age at marriage with the approval of parents is 18 years for the boys and 16 years for the girls and that without the consent of the parents is 21 years for the boys and 18 years for the girls. Despite this legal provision, early marriages are still held in the rural areas of Nepal.

According to 1991 census, the literacy rate for males and females is 54.4 and 25.0 percent respectively so that marriages are held earlier because they do not have much choices to do as educated people do have. Since the population is also predominantly rural in composition, marriages are held earlier than the urban population. Birth control advice and devices are inaccessible in many parts of rural Nepal and therefore, there is low level of contraceptive use. Uneducated rural people are also fatalists. Put in another way, they think that their fate determines their course of life. So people accept that having many children is also determined by their fate. This is also responsible for the rise of population.

Thus, the decline of mortality and morbidity without corresponding decline in the fertility rate, stoppage of permanent migration from hill to India and consequent internal migration to the Tarai, early nuptiality, low level of literacy, rurality of population in composition, lack of family planning devices and advice in most of the outlying parts of the country, fatalistic attitude, poverty, immigration from India, etc. have significantly contributed to the increase of Nepalese population which has, in tum, had the adverse effect on the fragile ecosystem of the counttry.

\section{Increasing Demands of Growing Population on the Environment}

Population growth has placed more increasing demands on the forest and pasture resources so that they are fast being depleted. Many beautiful hills of Nepal are getting extinct at present. It is estimated that the area under forest land had decreased by almost 40 percent in the last 30 years (Bajracharya, 1984 : 113). In 1963-64, a total of 6.4 million hectares forest accounted 45.5 percent land of the country. Though the Master Plan for Forestry Sector (1988) has written that Nepal has 37 percent land under forest cover, scholars on forestry estimate this percent as low as 29 percent. This shows that deforestation has taken place at an alarming rate in Nepal. Forest ecosystems have devel oped over long periods of time and get adapted to certain climatic and other ecological conditions. This balanced system suffers irreversibly when there is growing encroachment by burgeoning human population.

There appears to be a close correlation between the depletion of forest resources and the growth of population in Nepal. For example, population in the Eastern Tarai districts of Jhapa, Morang, Sunsari and Siraha during the period 1952-1971, doubled while the forest area was halved (Gurung, 1981:8). Increasing demands for cultivable land, firewood, fodder and timber have been responsible factors for the drastic forest reduction. In other words, deforestation is the function of the demand for firewood, timber, fodder and new cultivable land. The increasing demands of growing population on the forest environment have been succinctly discussed below.

\section{Increasing Demand for Cultivable Land}

Nepal has overwhelmingly an agrarian economy so that land is an important factor for growing food in order to feed the 
rapidly increasing population. As stated earlier on, Nepal has 18 million population and 45.5 percent of the total population of 18 million lives in the hills where only 0.6 million hectares of land is cultivable. Most of the forest and private pasture areas have already been encroached by the land-hungry population. In other words, the population of the hill exceeds the carrying capacity. Thus, the hill agriculture does not support the growing population so that they seek the alternative of their survival and the hill land hungry people have been migrating to the Tarai.

These hill migrants have ravaged the forest mercilessly in the Tarai. The problem of illegal squatters has also contributed a lot to the depletion of forests. Illegal settlement in the Tarai has been a problem for the government. As the ratio of population between the hills and Tarai goes in favour of latter as has been the trends in recent decades, forest cover in Tarai is and will increasingly be threatened. Some estimates claim that over 90 percent of the total forest cover has been encroached in the Tarai. If migration and consequent encroachment on forest land is the problem in the Tarai, in the hills, the problem is that of ever-increasing population pressures, leading to increasing demand for cultivable land and consequent deforestation (Bhatta, 1976 : 23). In the hills of eastern Nepal, there is now little jungle to break or virgin land to bring under cultivation. Given the existing level of technology and pattern of cultivation, the land is unable adequately to support the population (Caplan, $1970: 6)$.

Both hill migrants and Indian immigrants from the states of North India have destroyed the Tarai forests. It is clear that one indirect effect of deforestation in the hills is the drastic reduction of the Tarai forests by immigrants seeking land for settlement and cultivation. Both squatting and legal settlement are dependent on forest clearance, while the growing population is placing increasing demands on the dwindling forests (Seddon, 1987).

The population pressure per cultivated land for hill region is 9.6 persons which is very high (CBS, 1995). In the hills, the average size of holding is 0.77 hectares compared with 1.26 hectares in the Tarai (CBS, 1994). Thus, growing population is putting increasing pressures on forest environment for growing food. In discussing the implications of rapid population growth : Blaikie, Cameron and Seddon write :

The implication of (The) rapid growth of Nepal's population had become painfully clear, for the predominantly agrarian economy had shown itself only able to keep with the increase in population and its requirements largely through the cultivation of less productive land in the hills and the opening up forest in few plains. The first of these led to the development of widespread erosion following the massive destruction of the forest cover, while the second provided only a temporary safety-valve for surplus population from the hills ... (Blaikai, Cameron and seddon, 1980: 11-12).

Thus, the rapid growth of population has been a significant factor contributing to the depletion of forest resources.

\section{Increasing Demand for Firewood}

Closely associated with the foregoing point of population pressure is the increasing firewood demand which has been one of the principal factors of forest degradation in Nepal. Wood has remained a dominant domestic fuel for rural people. Firewood at present provides nearly 80 percent of the energy in Nepal (CBS, 1998). Per capita consumption of fuelwood for the hills is $640 \mathrm{~kg}$ and while for the Tarai, the figure is $424 \mathrm{~kg}$ (Subedi, 1995).

Nepal lacks coal and other petroleum resources. And she has not been able to hamess water resources despite the high potentiality. Hence, people have to depend on firewood. Although forest is a renewable natural resources, the way in which it is used makes it non-renewable. The growing demand for bio-fuel from the forest is attributable to population growth in Nepal.

\section{Increasing Demand for Fodder}

Nepalese agrarian economy is dependent on livestockraising. Hoffpauir is of the view that cattle and water-buffalo are the key links in the ecosystem as providers of manure which, composted with wild vegetation, is used to fertilize the fields. The male cattle are necessary for ploughing the terraces and the 
buffaloes are used primarily as manure machines, but can also occasionally produce milk and offspring (quoted in Poffenberger, 1980 : 47). Livestock is usually held in excessive numbers in the Himalayas, partly for religious reasons, partly on account of the low yields of cattle, and partly because of the need for animal manure. Livestock makes demands on the forests in two ways. First, the forest is used for grazing all the year round, and leaves and twigs of small trees. Second, the leaves and twigs are lopped for cattle feed by the population.... (Rieger, 1976 : 18). Livestock-raising is entirely dependent on fodder resources. Forest and pasture are the principal sources of fodder. Forest-fodder supply is very important source of livestock food in hill areas. Estimates place amount anywhere from 40 to 60 percent of the total fodder consumed (Macfarlane : 1976. 45).

The rural people feel that the importance of the forest is to provide fodder to livestock. One of the simple reasons for the forests near the villages being misused is that very many peasants have no alternative source to get their fodder. According to the 1991/92 national sample census of agriculture, Nepal has 7.37 million cattle, 3.12 million buffaloes and 5.52 million goats. Analogously, there are 602,800 sheep and 495,800 pigs (CBS, 1994). This places her among those countries with the highest livestock population per unit of land.

To sustain this present livestock population, Nepal needs more than 90 million tons of fodder per annum. The agricultural economy of Nepal is entirely based on the bio-mass extraction from the neighbouring forest. The utilization of animal manure is possible to the farm lands only through the exploitation of fodder resources from the forest ecosystem.

The excessive livestock population is raised in order to meet the nutritional requirements of the rural poor people. Environmentalists hold the opinion that overgrazing by the excessive herds of livestock population has been one of the principal factors of ecosystem degradation. Very often the individual farmer does hardly to safeguard, take care of, utilize the few fodder species. Thus, a farmer who uses the forest today as his fodder sources may be the one destroying it at a rate faster than would like to believe. The damage left behind by the migrating herds of Chories (a variety of cow found in high altitude) in search of fodder can be devastating to the forest in the cooler areas. The pressure of man and his animal population on the forest and pastures have reached its saturation point (Pandey, 1976: 19).

\section{Increasing Demand for Timber}

The rapidly growing population places increasing demands of timber on forest for building houses for shelter. People exploit timber more than their actual demands. Regarding this, Mauch writes that in the central Himalayas about 70 cubic meters of valuable wood is logged per house, although less than 20 cubic meters would suffice if properly and efficiently used (Mauch, 1974 : 9).

\section{Environmental Degradation in Nepal}

The rapid depletion of forest resources due to unprecedented population growth has caused a serious environmental degradation in Nepal. Eckholm writes that there is no better place to begin an examination of deteriorating mountain environments than Nepal. In probably, no other mountain countries are the forces of ecological degradation building so rapidly and visibly (Eckholm, 1976 : 76). It is obvious that the destruction of hill forest, through the destruction of the previously balanced environment, is indirectly resultant in the destruction of the forests in the Tarai for the growing population is placing increasing demands on the dwindling forests for cultivable land, firewood, fodder and timber (Rieger, 1976). Conclusively, forest plays a significant role in maintaining the ecological equilibrium. The deforestation adversely affects the previously balanced ecology and consequent are the environmental problems. The main environmental problems of Nepal are discussed hereunder.

\section{Denudation}

Denudation, an appalling environmental problem, means taking away of tree covering from the land. The problem of denudation has been universal in many hill regions of Nepal. 
But the problem of denudation is not new in Nepal although its pace has been accelerated in the recent decades. Large areas of far western hills have been denuded of forest... however, deforestation especially the removal of forest cover from the tops of ridges and hills in many areas has presumably lessened the moisture retaining capacity of the soil, a critical factor in this region which has low and uncertain rainfall (McDougal, 1978 : $3-4)$. Denudation is the consequence of the increasing pressure of human population and ruminant populations on the forest resources.

\section{Soil Erosion}

Closely associated with the problem of deforestation is the problem of soil erosion. Every year Nepal faces the problem of soil erosion. The main reason of rapid increase in soil erosion is the massive exploitation of natural resources of the country owing to the overpopulation. In Nepal, unrestricted and unscientific terraced cultivation, deforestation and the excessive overgrazing have been conducive to the tremendous deterioration of the environment which, in turn, have been increasing the rate of erosion. Soil erosion is a great ecological hazard which has negative impact upon the lives of human beings. Soil erosion destroys the normal equilibrium in the relation between man and nature.

There is also the natural erosion but man-made erosion is relatively dangerous. Deforestation and soil erosion are inseparably linked with each other. Nepal is predominantly an agrarian economy and the soil is highly precious for the production of the basic necessities of Nepal. But this goes unnoticed during the monsoon. Soil erosion is Nepal's most precious export, for which it receives no compensation. An estimated 240 million cubic meters of soil are lost every year (IBRD, 1974 : Annex $6: 2$ ).

Soil erosion in Nepal, as in many other countries elsewhere, is caused by the pressure of large rural population which only understands and practices primative and destructive methods of cultivation. Land is cultivated to the limit of production without thought being given to its preservation and improvement. Vast number of generally inferior cattle and goats are allowed to wander freely and everything within reach, whether this is in the form of pasture, grasses, shrubs or young trees. Everywhere, in the hills, the trees, whose fodder value is considerable, are lopped not according to any systematic cropping pattern, but in the most hapazard and destructive manner possible where small patches of forest or shrub still survive are subjected to lopping (Willan, $1967: 15$ ).

Many studies have shown that Kosi (one of the biggest river of Eastern Nepal) catchment of Eastern Nepal is one of the most eroded areas in the world. Soil erosion has been a direct challenge to the people of Nepal. Soil erosion is almost to the point of no return. It is apparent that the continuation of the present trends may lead to the development of semi-desert ecology in the hilly regions (Quoted in Eckholm, 1976 : 82).

\section{Landslide}

Landslides are often frightening experiences. They occur when a great mass of soil lying on steep slope becomes saturated with moisture and slides over the underlying rock surface. There may be natural landslide too, but human intervention on nature (especially on forest ecosystem) has increased the frequency and gravity of landslide. Mountainous country like Nepal faces the problem of soil erosion. It has become an inescapable economic problem. Every year, during the period of monsoon, landslides have taken the toll of human lives and of cattle and have destroyed houses. The long cause for the landslides is the expansion of agriculture up to steep hill slides and the progressive defoliation of the hill slides that should have left with trees. The hillsides are highly unstable when tree cover is removed (Schoader, $1977: 133$ ). 


\section{Siltation}

Siltation has been another environmental problem in Nepal. Because of erosion and frequent landslides, the rivers are filled with heavy load of silt in the summer. When the rivers emanating from the snow-capped mountain reach the Terai belt, their movement is slow so that silt is dropped and thereby the river beds are raised. River beds in the Terai are rising at the rate of about 15-30 centimeters ( 6 inches to 1 foot) a year (National Planning Commission, 1974b). This siltation causes further heavy floods during monsoon season and thereby diverts the usual river beds and all of which contribute to the destruction of irrigation canal structures and heavy toll of human settlements.

Thus, the rapid growing population has placed increasing demands on the dwindling forests for cultivable land, firewood, fodder and timber for the construction purposes. And consequent is the environmental deterioration which has ultimately worsened the economic base of the poor country, Nepal. Besides these above-mentioned environmental problems, the gradual process of desertification in some parts of hill and the Tarai has become another serious problem.

\section{Impact of Degraded Environment on the Economy of Nepal : A Glimpse of Agrarian Change}

Nepal has predominantly an agrarian economy supported by livestock-raising. Livestock-raising is the fundamental component of Nepalese farming system. Agriculture and livestock-raising are inseparably interrelated but the latter is totally dependent on the forest fodder and forest grazing lands. During the recent decades, fodder from private pastures (disappeared due to excessive ruminant population) and forest has declined considerably due to the uncontrolled population growth, overgrazing, and uncontrolled and haphazard method of lopping. As a result, the number of livestock has started either to decrease or get malnourished and thin. All this has resulted in the decline of agricultural yield of the villages of Nepal. Decline of agricultural productivity means decline of the by-products of agriculture which are also used as feeding resources. This fodder shortage has had the negative impact on the peasant economy of Nepal. Diagrammatically, this negative impact is as follows :

\section{FIGURE 1 : IMPACT OF POPULATION GROWTH ON THE PEASANT ECONOMY}

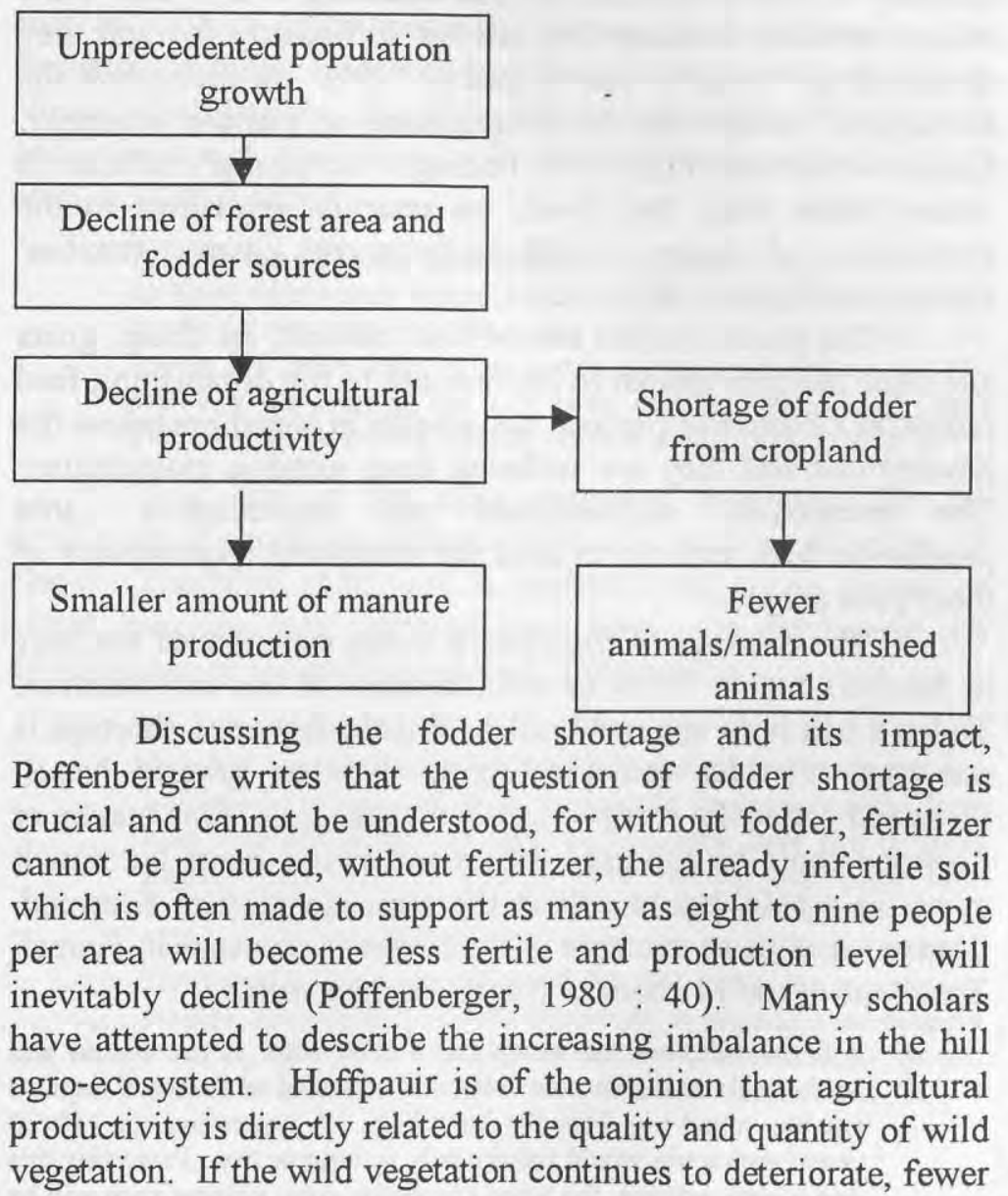


animals will be kept, small amounts of manure will be produced, crop yields will decline and people will have less to eat. Lower crop yields also result in less straw fodder, which means further limitations on the number of animals and an added force driving this downward spiralling system (quoted in Poffenberger, $1980: 53$ ).

Milk yield among the peasant households has already started to decline due to the shortage of fodder resources. Income from clarified butter has almost become a day dream for most of the households although very few are having it till now. Quantity of milk production is also declining every year. Now animals are thin because they are not sufficiently fed and they cannot give a desired yield (Uprety, 1986). In discussing the shortage of fodder and its consequence on peasant economy, Caplan writes that villagers are finding it increasingly difficult to obtain fodder from the forest, an essential ingredient in the production of butter which supplements many families' economies (Caplan, 1972 : 35)

The practice of the sale of meat animals, i.e. sheep, goats and pigs, has also started to decline due to the diminishing feed resources. Forty two percent households in Nepal are below the poverty line and they are suffering from extreme malnutrition. The excessively malnourished and unproductive cattle population does not help to meet the nutritional requirements of these poor people.

The shortage of firewood is being experienced not only in the hills but in Tarai as well, because of the deforestation. Today it has been apparently clear that the firewood shortage is one part of wider ecological crisis that has gripped Nepal. Firewood collection was previously an easy task. One bundle of firewood could be collected within one or two hours but now it takes the whole day to collect the same quantity of firewood. Illustrating with an example of the firewood shortage in Kamali Zone (one of the 14 zones of Nepal), Bishop writes,

It is the rule, not the exception, that in most of the central and southern Kamali zone, the collection of a load of firewood requires one-day round trip from the household. A generation age $(18+20$ years) such a trip would require only an hour or two. Projecting this rate of deforestation, the wood supply for many villages soon will be more than a day away. The villagers will not be able to afford the increased time required for obtaining wood. They will be forced to burn dung as is now done in lower regions of Nepal. ... Thus, negative chain reaction will take place (Bishop, 1970 : 33-33).

This above case demonstrates that when the shortage of food grows worse, the negative feedback increases. When there is local shortage of fuelwood, dried dung has to be used as fuel energy. As a result, there is less manure available for agriculture and this, in turn, has a negative effect on soil and results in declining crop yields because this type of feedback demands are automatically placed on the forests and pastures. Therefore, another vicious cycle naturally shows its ugly head. The depletion of forest resources has aggravated the soil erosion in Nepal which has the crippling effect on the animal husbandry and subsistence agriculture. In discussing the effect of soil erosion, Robbe writes :

It seems extraordinary thing that in a poor mountainous country such as Nepal where every foot of soil is precious and required to produce the basic necessities of life in the shape of food and shelter, the brown soil-laden rivers go unnoticed during the monsoon, and the fact they are carrying the very basic of life of the people mean nothing at all to the vast majority (Quoted in Eckholm, 1976: 81).

Thus, soil is the most important ingredient for the production of cereals in a characteristically agrarian economy of Nepal. Therefore, if the soil is washed away, rural people of Nepal lose the very basis of their lives. In discussing the deterioration of hill agro-ecosystem, Enke writes :

Visual evidence of already existing over population includes deforestation, erosion, and silting. Within the last decade, wooded hill tops have been cut down or severely depleted, terraces have been extended to the tops of hills and cattle have had to graze further away, hill-top terraces have leached out, have been abandoned, and have started to collapse on terraces below. Villagers often have to go much further to cut fodder for animals. The complex interaction of wood for fuel, cattle for manure and draught, and manured terraces for rice etc. is becoming increasingly vulnerable to overcrowding of the hill areas. If conditions worsen, areas now cultivated will have to be abandoned (Enke, 1971:20). 
Thus, the environmental degradation, a function of population growth has had a collasping effect on the subsistence agrarian economy of Nepal.

\section{Concluding Remarks}

Now Nepal has experienced an unprecedented population growth, that is 2.1 percent per annum. It is the function of a multiplicity of factors which comprise the decline of mortality and morbidity without the corresponding decline in the fertility rate, malaria control and stoppage of permanent migration from hill to India and consequent internal migration in the Tarai, early nuptiality, lack of education, economic value of children, rurality of population in composition, unavailability of contraceptive devices in outlying parts, poverty, fatalistic attitude and immigration from India. The population growth has been conducive to generate the grave environmental problems such as deforestation, denudation, soil erosion landslide, siltation and flood havoc. The population pressure is expressed in several ways which include increased demand for cultivation, increased livestock population and increased use of remaining forest to meet rising fodder, fuelwood and timber demands. The degraded environment has negative effect on the agrarian economy of Nepal. Nepal, the unexcelled land of beauty in south Asia, has already experienced the shortage of firewood, fodder, timber and new patches of cultivable land because of population pressure. Consequently, the subsistence agrarian economy is increasingly being vulnerable due to the deterioration of the environment. Based on the analysis, the author would argue that the environmental plight of Nepal can be healed if government adopts the following programs forthwith : (i) develop alternative sources of energy such as exploitation of perennial water resources to generate hydroelectric power, develop solar power, wind power and bio-gas technology; (ii) develop and disseminate the technology of improved stove to save energy consumption in villages; (iii) create awareness among the farmers to plant fodder frees in the private land; (iv) expedite the implementation of governmental strategies for massive reforestation, afforestation and forest protection programs with people's participation; (v) formulate national level policies to divert the under-utilized labor force of hill agriculture to other sectors such as agro-based industries as an incentive to check hill to Tarai migration and thereby halt deforestation in the latter; (vi) provide basic environmental education to the rural population regarding the conservation of nature; (vii) introduce programs to raise the socio-economic status of households by providing education so that the fertility rate would be lowered (because the recent positive attitude towards family planning is pronounced more among the urban educated and relatively economically prosperous elite circles); (viii) accord top priority in Nepal's family planning program to make birth control measures available to households of remote villages on a regular basis with adequate follow-up programs and (ix) regulate the open border between Nepal and India with the objective of checking the Indian immigration.

The author would believe that if these programs are still timely executed, the deteriorated mountain environment of Nepal would be reverted and the future generations would not be deprived of the right to exploit the environment on sustainable basis for their physical survival. Then, the age-long practiced saying, "Green forests are the wealth of Nepal", which is now obsolete, will be again a realistic saying.

\section{REFERENCES}

American Public Health Association

1979 A Health and Population Brief, Kingdom of Nepal. (Mimeographed) Washington, D.C. American Public Health Association, International Health Programs.

Aryal, Deepak, et. al. (eds.)

1982 Nepal District Profile. A District-wise SocioEconomic Profile of Nepal. Kathmandu : Nepal Research Associates.

Bajracharya, M.K. 1984

"Forests" Nepal's Nature's Paradise. Bangkok : White Lotus Co. Ltd. 
Banister, Judith and Thapa Shyam

1981 The Population Dynamics of Nepal. Honolulu, Hawaii : East-West Population Institute. No. 78.

Bhadra, Binak

1982

Natural Resources in Nepal and Regional Context. Kirtipur: CEDA.

Bhatta, Dibya Deo

"Energy and Environment : A Search for Better Alternative" Current Issues in Nepalese Development. Kirtipur: CEDA.

Bishop, Berry

1970

A Cultural Ecological Analysis of Karnali Zone in the Western Himalayan with Emphasis on Movements of People, Animals and Goods, Seasonality and Recent Change. Washington, D.C. : National Geographic Society.

Blaikie, Piers, John Cameron and David Seddon

$1980 \quad$ Nepal in Crisis. Growth and Stagnation at the Periphery. Oxford University Press, Oxford.

Caplan, P. A

1972

Priests and Cobblers. San Francisco, CA., U.S.A. Shandler Publishing House.

Caplan, L.

1970

Land and Social Change in East Nepal. Routledge and Kegan Paul, London.

Central Bureau of Statistics, Nepal

1958

Population Census 1952/54. Kathmandu.

Central Bureau of Statistics, Nepal

1961 Population Census 1961, Vol. III, Part 2. Kathmandu.

Central Bureau of Statistics, Nepal

1975 Population Census, 1971, Vol. I, Kathmandu.

Central Bureau of Statistics, Nepal

1977 The Analysis of the Population Statistics of Nepal. Kathmandu.
Central Bureau of Statistics, Nepal

1984 Population Census 1981, Vol. II. Kathmandu.

Central Bureau of Statistics, Nepal

1985

Intercensal Changes of Some Key Census Variables, Nepal. 1952/54-81. Kathmandu.

Central Bureau of Statistics, Nepal

1995 Population Monograph of Nepal. Kathmandu

Central Bureau of Statistics, Nepal

1998 Statistical Pocket Book. Kathmandu.

Eckholm, Erik P

1976

Losing Ground. New York: W.W. Nortan and Company.

Enke

1971

"Projected Costs and Benefits of Population Control" in Population Development, CEDA, Kathmandu.

Gurung, Harka

1981

Ecological Change in Nepal. A Native Interpretation. New ERA. Kathmandu, Nepal.

Marris, Marvin

1974

Cows, Pigs, Wars and Witches : The Riddles of Culture. New York: Vintage Books. A Division of Random House.

International Bank for Reconstruction

and Development (IBRD)

1974 Nepal Agriculture Sector Survey. Vol. 3 Washington, D.C.

Kansakar, V.B.S

1977

Population Census of Nepal and the Problem of Data Analysis. Kirtipur : CEDA.

Kansakar, V.B.S.

1989

"Population of Nepal" in Perspectives on Continuity and Change, CNAS, Tribhuvan University, Kirtipur, Nepal. 
Macfarlane, Alan,

1976 Population and Resources. Cambridge. Cambridge University Press.

Mauch, S.P.

1976

"Energy Situations in the Hills : Imperative for Development Strategies" in Mountain Environment and Development. Tripureshwor : Sohagi Press. SATA.

Mauch, S.P.

1974

Long Term Perspective of the Region's Forest Resources and the Associated Availability of Firewood, Cattle, Fodder and Construction Materials for the Local Population Zurich : Integrated Hill Development Project Reproduced.

Nepal, Family Planning/Maternal and Child Health Project (EP/MCH Project)

1977 Nepal Fertility Survey, First Report World Fertility Survey Nepal Project. Kathmandu : His Majesty's

Government, Ministry of Health, Nepal FP/MCH Project.

Nepal, National Planning

Commission Secretariat

1974

A Draft Proposals of Task Force on Land Use and Erosion Control. Kathmandu. His Majesty's Government : National Planning Commission.

Pandey, K.K.

1977

"The Fodder Situation and the Potential of Additional Resources" in Mountain Environment and Development. Tripureshwor : Sahogi Press. SATA.

Poffenberger, Mark

1980

Patterns of Change in Nepal Himalayas. New Delhi, India : The Macmillan Company of India Limited.
Rajbhandry, H.B. and Shah S.S.

1981 "Trend and Projections of Livestock Production in the Hills" Nepal's Experience in Hill Agricultural Development. Kathmandu. Ministry of Food and Agriculture, His Majesty's Government.

Regmi, M.C. 1987

Thatched Huts and Stucco Palaces. Peasants and Landlords in $19^{\text {th }}$ Century Nepal. New Delhi : Vikas Publishing House.

Rieger, H.C

"The Himalayas and the Ganges and an Ecological System" in Mountain Environment and Development. Tripureshwar: Sohogi Press. SATA.

Rieger, H.C. et. al

1976

Himalayan Ecosystems Research Missions Nepal Report South Asia Institute, University of Heidelberg, Heidelberg.

Schroder, RF

1977

Ecological Change in Rural Nepal, Ph.D. Dissertation in Anthropology. University of Washington.

Seddon, David

Nepal: A State of Poverty. Vikas Publishing House, Pvt. Ltd. Ansari Road, New Delhi.

Shrestha, R.L.

1984

"Ecosystem of Nepal Himalayas" Nepal-Nature's Paradise, Bangkok: White Lotus Co. Ltd.

Subedi, Bhim P.

1995

"Population and Environment in the Context of Sustainable Development in Nepal" in Population Monograph of Nepal, Kathmandu

Uprety, Laya Prasad

1984

The Role of Forest Resources in Village Economy : An Ecological-Anthropological Case Study of Gogangaun. A Dissertation Submitted to Tribhuvan University in partial fulfillment for the requirements for M.A. in Anthropology. 
Uprety, Laya Prasad

1986

Fodder Situation : An Ecological-Anthropological Study of Machhegaon, Nepal. HMG-USAID-GTZ IDRC FORD- Winrock Project, Food and Agricultural Sector in Nepal.

Willan, R.C.M.

1976

Forestry in Nepal. Kathmandu

World Bank 1979

Nepal Development Performance and Prospects. Washington, D.C.

World Bank 1981
Staff Appraisal Report of the Hill Food Production Project. Washington, D.C.

\section{GENDER ROLES AND ACTIVITIES AMONG THE RURAL POOR HOUSEHOLDS: CASE STUDIES FROM HILL VILLAGES}

\section{Binod Pokharel ${ }^{*}$}

Biologically, human societies are stratified into men and women dichotomies. All the known societies are unequally distributed. In small food producing societies, the inequality is limited to dyadic and non-categorical prestige bases (Pathy, 1987). There is some sort of identified division of labour between male and female in every kind of society. But, Marx stated that every form of society presupposes some rudimentry division of labour. Likewise, Mair (1999) views that the biological division of human into male and female is the basis of the most elementary social stratification everywhere. The division of labour means the fact that women bear and suckle children, and are tied to the domestic sphere for much of their lives. Wolf considers social inequality not as phenomena sui generis but as an accompaniment of the working out of determinental modes of production (quoted by Pathy, 1987).

After 1990s, the gender relationship between male and female has emerged as one of the major issues in Nepal. This issue draws the attentions of scholars, professionals, politicians and public and policy makers. Gender is defined as socially and culturally constructed accepted behaviours and relations between male and female. Behaviours and relations are structured in the society. In other words, most of the behaviours and relations are deeply rooted in social, cultural, political, economic and religious frameworks. In some traditional societies, the gender roles are more rigid than in urban and industrial societies. The

\footnotetext{
- Mr. Binod Pokharel is the Lecturer in Anthropology at the Central Department of Sociology and Anthropology, Tribhuvan University, Kirtipur, Kathmandu.
} 